\title{
New Strategies to Improve Sensorial Quality of White Wines by Wood Contact
}

\author{
M. Elena Alañón ${ }^{1, *} \mathbb{C}$, M. Consuelo Díaz-Maroto ${ }^{1}\left[\right.$ and M. Soledad Pérez-Coello ${ }^{2}$ \\ 1 Area of Food Technology, Regional Institute for Applied Scientific Research (IRICA), University of \\ Castilla-La Mancha, Avda. Camilo José Cela, 10, 13071 Ciudad Real, Spain; mariaconsuelo.diaz@uclm.es \\ 2 Area of Food Technology, Faculty of Chemical Sciences and Technologies, University of Castilla-La Mancha, \\ Avda. Camilo José Cela, 10, 13071 Ciudad Real, Spain; Soledad.perez@uclm.es \\ * Correspondence: mariaelena.alanon@uclm.es; Tel.: +34-926295300; Fax: +34-926295318
}

Received: 31 October 2018; Accepted: 16 November 2018; Published: 21 November 2018

\begin{abstract}
Ageing wine is a common practice used in winemaking, since the quality and sensory profile increase due to the extractable compounds coming from wood, by means of barrels or chips. The quantitative and qualitative compounds of the wood depend on the species, its origins and the treatments applied in cooperages. Traditionally, oak wood species are most often used in cooperage, specifically Quercus alba (Q. alba), Known as American oak and Quercus robur (Q. robur) and Quercus petraea (Q. petraea), both known as French oak. Although this stage is very common for red wines, its use is still restricted in the case of white wines. However, this topic is particularly interesting, since due to the sensorial benefits of wood contact, the option for ageing white wines in barrels or chips could be chosen by winemakers. This review compiles the novel strategies applied to white wines by means of wood contact in recent years with the aim to increase wine quality and sensorial features.
\end{abstract}

Keywords: white wine; volatile compounds; sensorial characteristics; oak; alternative woods; barrels; chips

\section{Introduction}

The white wine market has been monopolized for many years by young varietal wines, which should be consumed in a short period after bottling to avoid the loss of freshness and fruity character, mainly due to the detriment of the compounds of varietal origin. Different oenological practices were used to enhance varietal aromas in slightly aromatic or neutral white grape varieties, such as pre-fermentative skin-contact treatment or the use of glycosidic enzymes, to obtain more aromatic wines with a low content of phenolic compounds [1-3].

Wood ageing in the case of white wines has only been used occasionally, mainly by fermentation in barrels or by ageing on lees $[4,5]$. The yeast cells absorb the ellagitannins from the wood, reducing the astringency of the wines, while some compounds extracted from wood such as furfural and vanillin can be metabolized by the yeasts decreasing their sensory impact [6].

Recently, these techniques have been recovered together with other alternative practices in white vinification, such as the use of chips which are allowed in some countries. Fermentation and/or ageing in wooden barrels, accelerated ageing with wood chips, ageing in barrique on lees [5,7-9] and the use of other types of wood such as acacia or cherry $[10,11]$ have been used to improve the quality of white wines.

Different authors have studied the volatile composition of different woods for potential use in enology [12-14]. Table 1 shows the concentration of some of the main volatile compounds found in those "new" woods, such as chestnut, acacia or cherry, along with the components of the oak woods traditionally used in the aging of wines. 
All these innovations have contributed to increasing and improving the variety of white wines in contact with wood in the market, adapting to the new tastes of the consumer and the demands of the international market. However, it is important to look for the best combination between type of wood, ageing process and grape variety in order to obtain a quality wine with new sensory sensations, but without masking the primary and secondary aromas specific to each grape variety.

Table 1. Volatile composition ( $\mu \mathrm{g} / \mathrm{g}$ ) of different untoasted woods with potential use in enology $[13,14]$.

\begin{tabular}{ccccccc}
\hline Compounds & $\begin{array}{c}\text { American Oak } \\
(\mathbf{Q} \text {. } \text { alba })\end{array}$ & $\begin{array}{c}\text { French Oak } \\
(\mathbf{Q} \text {. petraea })\end{array}$ & $\begin{array}{c}\text { French Oak } \\
(\text { Q. robur })\end{array}$ & Chestnut & Acacia & Cherry \\
\hline Furfural & 5.79 & 12.09 & 17.90 & 3.55 & 0.56 & - \\
5-Methylfurfural & 0.41 & 3.57 & 4.95 & 2.34 & 0.05 & - \\
3-Oxo- $\alpha$-ionol & 0.03 & 0.55 & 1.10 & - & - & 9.17 \\
trans-Oak lactone & 1.64 & 2.14 & 2.87 & - & - & - \\
cis-Oak lactone & 39.37 & 6.12 & 3.19 & - & - & - \\
Guaiacol & 0.91 & 4.46 & 4.22 & 5.24 & 0.10 & 0.16 \\
Methylguaiacol & 0.24 & 1.11 & 0.92 & 1.51 & - & 0.01 \\
p-Vinylguaiacol & 3.37 & 3.42 & 4.58 & 2.99 & 0.37 & 0.65 \\
Syringol & 0.41 & 3.42 & 3.18 & 3.18 & 0.16 & 0.10 \\
Eugenol & 3.44 & 1.05 & 1.39 & 2.53 & 0.92 & 0.11 \\
Vanillin & 70.37 & 45.69 & 6.40 & 80.90 & 4.70 & 4.68 \\
Isoeugenol & 0.36 & 0.30 & 0.15 & 1.24 & 1.19 & 1.31 \\
Acetovanillone & 2.73 & 3.41 & 0.47 & 4.77 & 0.14 & 0.17 \\
Propiovanillone & 1.92 & 1.64 & 1.11 & 0.62 & - & 1.37 \\
Butyrovanillone & 7.40 & 6.86 & 2.15 & 10.16 & 0.47 & 1.32 \\
4-Allylsyringol & 0.92 & 0.89 & 0.63 & 1.46 & 0.45 & 1.13 \\
Syringaldehyde & 23.21 & 26.13 & 24.38 & 21.90 & 12.23 & - \\
Ethyl vanillate & 1.88 & 6.54 & 5.29 & 2.68 & 1.16 & 0.20 \\
4-Propenylsyringol & 1.60 & 3.10 & 1.25 & - & 0.87 & 0.99 \\
Coniferaldehyde & 23.11 & 29.05 & 25.87 & 29.20 & 9.76 & 2.72 \\
Sinapaldehyde & 4.34 & 7.67 & 6.30 & 5.24 & 10.56 & 3.56 \\
\hline
\end{tabular}

\section{Sensorial Quality Improvement of White Wines by Contact with Oak Wood}

In recent years, oenological research has not only focused on the ageing of red wines. There are more and more studies on the contact between white wine and wood, either during the ageing stage and/or during alcoholic fermentation. In this sense, the selection of wood type is fundamental. The barrels traditionally used are those of American oak (Quercus alba) and French oak (Q. robur and $Q$. petraea), the latter having the most prestige in the market and, therefore, also higher price. Both species are not exclusive to France, but extend across Eastern Europe and the North of the Iberian Peninsula, so lately Hungarian, Russian or Spanish oak barrels have been introduced into the market. These new oak woods present a similar volatile composition to that of French ones, and they are a good alternative in the ageing of wines $[15,16]$.

The knowledge of the chemical composition of oak wood, especially its content in volatile compounds and ellagitannins, is of great importance to select the most suitable oak for the ageing of a particular wine. During ageing time, the transfer of several chemical substances takes place from the wood to the wine, which will condition the sensory characteristics of the final product. In different studies, it has been shown that there are very few chemical characteristics of a single oak species. On the contrary, there is a great variability within each species and even within each geographical area $[15,17]$, since the climate and forest conditions have a great influence on chemical composition of oak wood [18]. Moreover, the physical and mechanical parameters of the wood (porosity, grain size, flexibility, etc.), can have an important influence on the transfer of substances between wine and wood, for that reason, the most appreciated species are those commonly known as "porous ring" woods, such as the oak. 
To provide the woody character to white wines, fermentation or ageing in oak barrels have been carried out. However, compared to red wines, there are few studies on the effect of the interaction between oak wood barrels and white wine. Although, one of the most suitable white grape varieties to ferment the must or to age the wine in oak barrels is Chardonnay [5,19-22]. In the literature, different studies about the influence of oak maturation on the quality of white wines from other varieties can be found, such as Verdejo [23], white Listán [24], Muscatel [25], Sauvignon blanc [20,22], Encruzado [26] or Malvazija istarska [9].

Herrero et al. [22] studied the effect of toasting level and ageing time on the volatile composition and sensory quality of two white wines, Chardonnay and Sauvignon blanc, aged in oak barrels. The differences observed in the content in wood-extractable volatile compounds of wines were mainly dependent on the toasting level and ageing time. The volatile compounds released by the oak wood into wines increased with the ageing time, except methyl vanillate and vinylphenols, which decreased, although the authors found a high variability among replicates, which has been previously reported in other works [21]. From a sensory point of view, Chardonnay and Sauvignon blanc wines 12-month aged in French barrels did not show an homogeneous aroma quality among judges [22]. Previous studies that had evaluated the impact of ageing in oak barrels in Chardonnay wines are by Spillman et al. [19] and Herjavec et al. [20], among others. The former established correlations between the volatile composition and the olfactory profile of wines aged in new oak barrels and confirmed the role of some oak wood-extractable compounds in aged Chardonnay wine aroma, such as the strong correlation between "smoky" aroma and volatile components produced by barrel toasting. While Herjavec et al. [20] observed a positive influence of the fermentation in new Croatian oak barrels on the sensory properties of Chardonnay and Sauvignon blanc wines, in comparison with those fermented in steel tanks.

The aroma quality of Chardonnay wines has also been tried to be improved by fermentation and ageing in oak barrels on lees. This technology allowed increasing the content of volatile compounds positively related to the quality of the wines' flavour. However, no significant differences were observed in the aroma of the wines compared to the fermented and aged wines in stainless steel, probably due to the stronger influence of lees in the aroma of the wines compared to oak wood [5].

On the other hand, Rodríguez-Nogales et al. [23] classified Verdejo wines obtained through different winemaking techniques based on their volatile composition and sensory characteristics. Verdejo wines fermented and aged in oak barrels shown greater amounts of eugenol and methyleugenol, and lower quantities of terpenes and esters compared to those young wines fermented in stainless steel tanks. More recently, Lukic et al. [9] increased the aromatic composition complexity of white wines by prolonged maceration followed by maturation in wooden barrels. The utilization of new oak wood barrels induced changes for some aroma descriptors, such as "wood aroma" and "aroma intensity" in Encruzado white wines [26]. The authors showed the important role of ageing time and barrel capacity on the quality of oak barrel-aged white wines. The major impact on the evolution of sensorial properties of Encruzado wines was observed in new oak barrels of $225 \mathrm{~L}$ during 180 aging days.

However, these oenological practices have some drawbacks such as the limited capacity of the barrels, mainly when they are used for wine fermentation, the difficulty to control the temperature of fermentation or the cleaning of the barrels. Also, not all wines are suitable for ageing in oak barrels since the micro-diffusion of oxygen through wood pores could oxidize the wine, and the release of chemicals into the wine could completely mask its sensorial characteristics [27]. In the case of white wines, oxidation causes a decrease in pleasant sensory levels along with the appearance of off-flavours as "honey-like" or "cooked vegetables", and the brown coloration of wine [28]. In this sense, oak wood chips are presented as a good alternative to the use of barrels for the ageing of white wines. Their price is less than that of barrels, however, the different behaviour of the chips has made the evolution of this technique slower than it might seem. 
Like barrels, chips can be used during fermentation or during wine ageing. Various authors have revealed the advantages of the fermentation of white wines in the presence of oak chips $[24,29,30]$. Airén wines were fermented with untreated chips from the most common oak varieties, American and French, at different doses, 4,7 and $14 \mathrm{~g} / \mathrm{L}$. Wines best valued by the tasters were those treated with $7 \mathrm{~g} / \mathrm{L}$ of American oak chips [29].

On the other hand, Gutiérrez Alfonso [24] compared from the sensorial point of view two Listán blanco white wines fermented with oak chips and in barrels. Chips from American and French oaks were added in two doses, 4 and $8 \mathrm{~g} / \mathrm{L}$, while new barrels of $225 \mathrm{~L}$ were made from the same type of oak. The variable with the greatest effect on the sensory profile of the wine was the amount of oak chips used, while the geographical origin of the oak was more noticeable in chips than in barrels. In this sense, wines fermented with the higher quantities of American oak chips showed the greater intensities of vanilla and coconut aromas, together a greater astringency than in barrels.

Recently, Sanchéz-Palomo et al. [30] tried to improve the quality of Verdejo white wines by using medium-toasted oak chips during the alcoholic fermentation of the must or during the ageing of the wine. Wines aged in the presence of chips showed the highest quantities of volatile oak-extractable compounds, such as oak lactones and furanic compounds, while wines fermented with chips had higher concentrations of fermentative volatile substances, as alcohols, acetates and ethyl esters of straight-chain fatty acids.

In respect to the use of oak chips during ageing, the volatile composition and the sensory characteristics of Chardonnay wines treated with chips of different oak species and toasting degree have been studied [7]. Table 2 shows the odour activity values (OAV) of volatile oak-related compounds in Chardonnay wines aged with non-toasted and toasted American (Q. alba) and Hungarian (Q. petraea) oak chips during 25 days, together the odour perception thresholds and odour descriptions of each compound are found in the literature [16,31-37]. Volatile oak-related compounds with higher OAVs were those quantified in wines treated with American oak chips. Compounds with OAVs $>1$ and with a possible impact on the aroma of the aged Chardonnay wine were cis-oak lactone, eugenol and 4-vinylguaiacol in wines treated with non-toasted American oak chips, and cis-oak lactone, eugenol, isoeugenol, guaiacol and vanillin in wines treated with toasted American oak chips. These results show the important effect that the toasting process has on the aromatic potential of oak, exhibiting those toasted oak samples higher number of compounds with OAVs $>1$. 
Table 2. Odour perception thresholds. Odour descriptions and odour activity values (OAV) of volatile oak-related compounds in Chardonnay wines macerated with non-toasted and toasted Hungarian (Q. petraea) and American (Q. alba) oak chips during 25 days.

\begin{tabular}{|c|c|c|c|c|c|c|}
\hline \multirow{2}{*}{ Compounds } & \multirow{2}{*}{ Odour Perception Threshold $(\mu \mathrm{g} / \mathrm{L})$} & \multirow{2}{*}{ Odour Description } & \multicolumn{4}{|c|}{ OAV } \\
\hline & & & NTA & TA & NTH & TH \\
\hline trans-Oak lactone & $122^{b}$ & Vanilla, oaky, clove, coconut ${ }^{\text {a }}$ & 0.36 & 0.14 & $0.00 *$ & 0.00 \\
\hline cis-Oak lactone & $35^{b}$ & Vanilla, oaky, clove, coconut ${ }^{a}$ & 9.11 & 3.17 & 0.00 & 0.00 \\
\hline Eugenol & $5^{b}$ & Spicy, clove, cinnamon a & 2.76 & 1.24 & 0.58 & 0.60 \\
\hline Isoeugenol & $6^{\mathrm{e}}$ & Spicy, clove, woody/oak ${ }^{a}$ & 0.37 & 1.98 & 0.45 & 1.32 \\
\hline Guaiacol & $15^{\mathrm{d}}$ & Spicy, toasty, smoky/burnt a & 0.29 & 1.33 & 0.13 & 2.63 \\
\hline 4-Vinylguaiacol & $141^{\mathrm{d}}$ & Smoky d & 1.08 & 0.50 & 0.99 & 0.96 \\
\hline 4-Ethylguaiacol & $46^{\mathrm{b}}$ & Toasted bread, smoky, clove ${ }^{b}$ & - & 0.09 & 0.01 & 0.13 \\
\hline Syringol & $570^{\mathrm{f}}$ & Smoky c & 0.02 & 0.12 & 0.01 & 0.16 \\
\hline Vanillin & $60 \mathrm{~g}$ & Sweet, vanilla ${ }^{a}$ & 0.16 & 1.48 & 0.16 & 2.26 \\
\hline Furfural & $15,000^{b}$ & Slightly toasty, caramel ${ }^{a}$ & 0.00 & 0.01 & 0.00 & 0.03 \\
\hline 5-Methylfurfural & $16,000^{b}$ & Spicy, toasty, sweet ${ }^{a}$ & - & - & 0.00 & 0.00 \\
\hline Maltol & $5000^{\mathrm{h}}$ & Caramel h & - & 0.05 & - & 0.01 \\
\hline
\end{tabular}

NTA: Non-toasted American; TA: toasted American; NTH: non-toasted Hungarian; TH: toasted Hungarian. * Those compounds with OAV equal to zero were detected in trace amounts in wines and could not be quantified. ${ }^{\mathrm{a}}[16],{ }^{\mathrm{b}}[31],{ }^{\mathrm{c}}[32],{ }^{\mathrm{d}}[33],{ }^{\mathrm{e}}[34],{ }^{\mathrm{f}}[35], \mathrm{g}[36],{ }^{\mathrm{h}}[37]$. 


\section{Sensorial Quality Improvement of White Wines by Contact with Alternative Woods to Oak}

Although oak is by far the wood most used to carry out the ageing process, in recent years several studies have been published relating to the effects of other woods such as chestnut, cherry and acacia in wine ageing [38-47]. However, the scientific researchers have been focused on the impact of the use of alternative wood species exclusively on the quality of red wines and not of white wines. Therefore, there is a restricted knowledge about the impact of alternative woods to oak wood on white wine quality during the ageing process.

Recently, the effect of chips from different types of woods such as acacia and cherry on the ageing process of Encruzado wines was evaluated in comparison with the traditional chips from American and French oak woods [11]. As consequence of the wood contact, all aged white aged wines had increased polyphenol content due to phenols transfer from wood to wine. However, those wines aged with acacia chips exhibited the highest total phenolic content $(342.94 \mathrm{mg} / \mathrm{L})$ in comparison with the rest of wines aged with cherry and oak wood $(328.59 \mathrm{mg} / \mathrm{L}$ and $319.86 \mathrm{mg} / \mathrm{L}$, respectively) [11]. The particular richness of some phenolic compounds in acacia wood, and consequently in wines aged in contact with this wood species, had already been reported by other authors [42,45]. However, contrary to this fact other authors evidenced a pronounced enrichment of model wines in polyphenolic substances in those model wines treated with oak chips compared to those treated with acacia or cherry, due to the significantly higher amounts of total extractable polyphenols of oak wood [48].

It is worthy to note that the contact of wood by means of chips with white wines implied a decrease on the browning potential index, due to the release of phenolic compounds from wood to wines. Phenomena such as the precipitation of oxidized phenols, the formation of phenolic polymers and the antioxidant properties of some phenolic compounds, lead to increases in the stability of white wines to oxidation [11]. This fact should be also confirmed in case of the use of barrels where a gentle flow of oxygen is produced through the wood pores, since no references regarding this have been found. Among all types of wood tested, those wines aged with cherry chips exhibited the higher browning potential values which pointed it out as the most sensitive to oxidation [11]. This fact was in consonance to low content of oxidizable polyphenols that characterized cherry heartwood [42,49].

From a sensorial point of view, it seems that white wines aged with acacia chips showed major colour intensity compared to those wines treated with cherry or American and French oak wood. Indeed, comparing the values of colour difference $(\Delta \mathrm{E})$ between control wine and wines aged in contact with different wood chips species, only white wine aged with acacia wood chips showed values higher than two CIELAB units, which is detectable by human eyes [11], being CIELAB the color space defined by the International Commission on Illumination (CIE).

On the other hand, the use of cherry and acacia wood seemed to impart to white wines, less aggressiveness and less woody character than oak wood. Furthermore, contrary to oak wood, acacia barrels appeared to enhance the sweetness and honey tastes and pronounce the vanilla and spicy character of Malvazija wines. These facts resulted in better overall appreciation scores for white wines aged with acacia than for those aged with oak or other woods $[11,50]$. However, the typical aged flavours described as spicy or vanilla were not detected in Chardonnay wines, a more international grape variety, aged in both acacia barrels and acacia chips [10]. The reasons of these facts were the low content of volatile phenols such as eugenol and guaiacol, the low level of vanillin and the lack of other substances contributing to vanilla flavour such as cis- and trans- $\beta$-mehtyl- $\gamma$-octalactone detected in wines aged with acacia. On the other hand, the sweetness character of wines aged in acacia was also confirmed by other authors who found new aged flavours coming from the contact with acacia wood described as nutty, honeyed and toasted [10]. Based on the literature, the responsible compounds for these new aromas seem to be 2-acetyl pyrazine, 2-acetyl-3-methylpyrazine and 2-acetylthiazole, which were identified as distinctive of acacia wood due to their powerful sensorial features described as toasty, popcorn and nutty [51].

Despite the fact that it seems that there is a clear preference for acacia wood against oak or other woods to carry out the ageing of white wines, crucial aspects related to ageing treatment (barrels or 
chips) and ageing time have not been elucidated yet. Therefore, our research group compared the traditional ageing technique of a Chardonnay wine by means of acacia barrels with the alternative practice of use acacia chips obtained from manufacturing acacia barrels. Both assays were performed in duplicate and acacia wood underwent a light toasting process. Sensorial properties of aged wines were monitored along four timing points, monthly for barrels during 4 months and weekly for chips during 4 weeks. After sampling was completed, wine control without acacia contact and all aged wines were submitted to a descriptive sensorial analysis to assess the best maturation process conditions with acacia wood, based on the sensorial properties.

In general terms, the emergence of new sensory features described from acacia wood, nutty, honeyed and toasted, appeared as a consequence of the acacia ageing of wines. These new pleasant sensorial features were clearly accentuated in wines aged in barrels during three and four-month ageing processes [10]. Furthermore, the new aged attributes were in good balance with varietal aromas coming from Chardonnay wine varieties. The perception of acacia ageing notes was imperceptible for those wines with less contact with acacia, a one month of stay in barrels and one week macerated with chips, which preserved better the fresh, fruity and varietal characters of young wine. The better retention of fruity characteristics of the original wine by the use of chips rather than barrels has been previously reported by other authors [38,52].

Among wine samples treated with acacia chips, those that were macerated for the three weeks aging process obtained higher scores by the panellists. Meanwhile, wines that were in contact with acacia during three and four months were the most regarded samples aged in barrels. Average values of each descriptor from the sensorial analysis of the highest scored aged wines in comparison with a control are shown by means of spider web diagrams in Figure 1. Compared to the use of barrels, the treatment with chips was scored lower by panellists. The use of chips led to a higher acidity and the attributes from acacia wood were timidly increased, leading to lower scores of taste intensity, taste quality and global quality. On the other hand, wines aged in barrels for three and four months exhibited a sensory profile different from the control. They resulted in high complexity due to the good balance between the varietal features of Chardonnay wine and the emergence of the new clearly perceptible sensory notes described for acacia wood, such as nutty, honeyed, and toasty, as a consequence of their contact with acacia barrels.
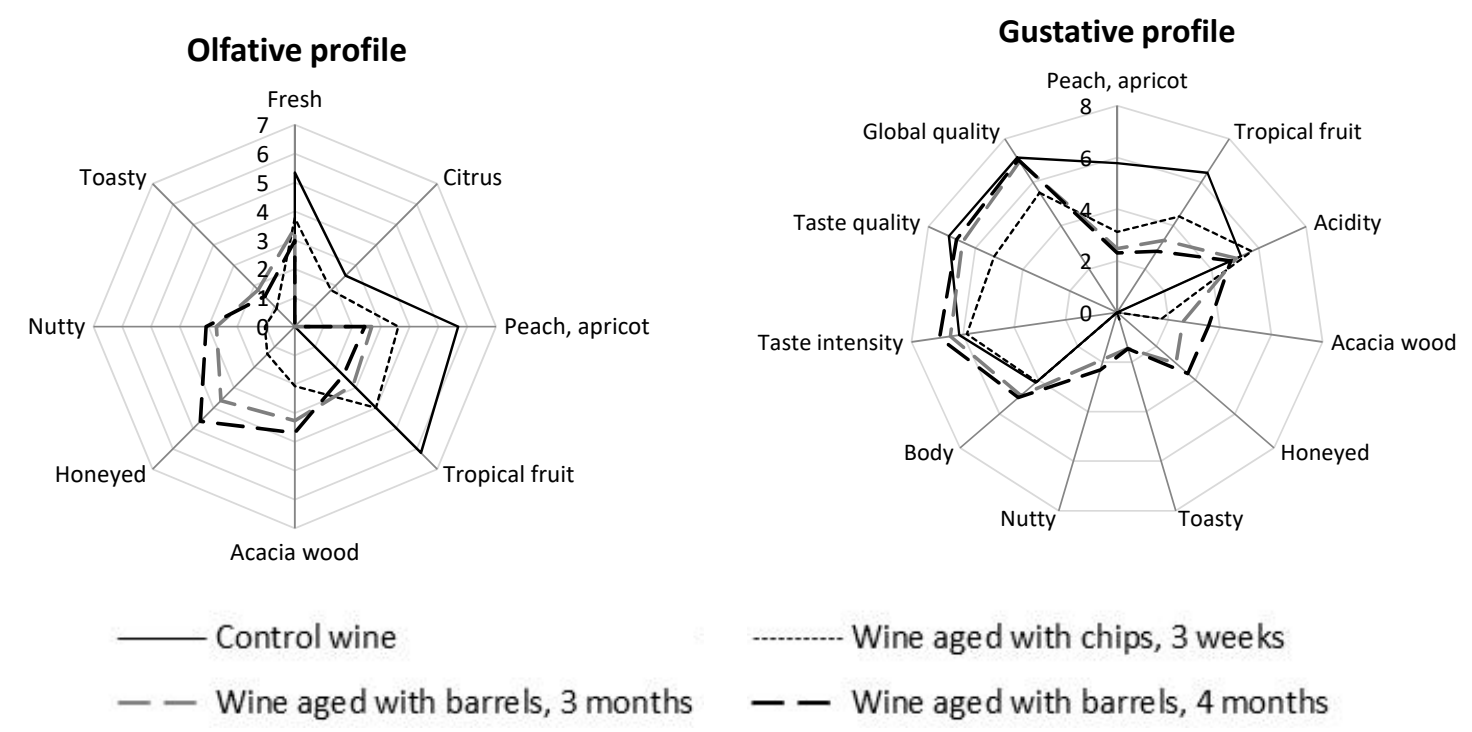

Figure 1. Olfactive and gustative profiles of aged wines with the acacia treatments best scored in comparison with sensorial profiles of control wines.

With the aim of looking for other alternative woods to carry out the ageing processes that might create unique flavours, an exploratory survey evaluated 12 wood species from New Zealand in 
comparison with American oak wood [53]. These wood species had never before used as flavourants in wine: Matai, Feijoa, Macrocarpa, Pohutukawa, Radiata pine, Totara, Kahikatea, Rimu, Cherry beech, Silver beech and Manuka were light and dark toasted in the manner of oak barrels and then used to infuse Chardonnay wines. Each wood showed different behaviours in terms of sensorial properties. In general terms, typical oaked wine descriptors such as woody, smoky, vanilla and buttery were provided by these woods. However, other unattractive sensorial features described as earthy, sappy, resin, paint stripper or pencil sharpening's were detected in one of the wood treatments. Based on a hedonic consumer trial, it was concluded that each wood could generate a flavour liked by some consumers, so wood species as yet untested may be useful in conferring unique flavours from a particular geographical region.

\section{Conclusions}

Although the ageing stage has been exclusive to red wines, in recent years, the effects of wood contact on white wines have been addressed by several scientific researchers. New white winemaking techniques such as fermentation with oak chips and barrels, or the ageing on lees entail sensorial advantages due to the highest quantities of volatile oak-extractable compounds. On the other hand, new wood species alternative to traditional oak wood species offer the possibility to flavour white wines in a different manner in which oak wood does. Therefore, the treatment of white wines with wood by means of technological innovations or the use of alternative woods from oak, not only might drive to an added-value on quality but also to the acquisition of unique flavours in white wines leading to diversification of market opportunities. However, in the majority of cases, scientific studies have been done with minority grape varieties, so further studies should be conducted with more international varieties, to address the effects of wood contact with white wines more deeply.

Author Contributions: The three authors contributed to the writing and correction of the paper. The conceptualization, M.S.P-C.; writing-original draft preparation, M.E.A and M.C.D-M.; writing-review and editing, M.E.A.; Supervision, M.S.P-C and M.C.D-M. All authors red and approved the final manuscript.

Funding: The Spanish National Institute for Agricultural and Food Research and Technology (INIA) supported this work: Project RTA2014-00055-C03-02.

Acknowledgments: M.E.A. thanks University of Castilla-La Mancha for the postdoctoral contract (Access to the Spanish System of Science, Technology and Innovation (SECTI)).

Conflicts of Interest: Authors declare no conflict of interest.

\section{References}

1. Sánchez-Palomo, E.; Díaz-Maroto, M.C.; González Viñas, M.A.; Pérez-Coello, M.S. Aroma enhancement in wines from different grape varieties using exogenous glycosidases. Food Chem. 2005, 92, 627-635. [CrossRef]

2. Sánchez-Palomo, E.; Pérez-Coello, M.S.; Díaz-Maroto, M.C.; González Viñas, M.A.; Cabezudo, M.D. Contribution of free and glycosidically-bound volatile compounds to the aroma of muscat "a petit grains" wines and effect of skin contact. Food Chem. 2006, 95, 279-289. [CrossRef]

3. Sánchez-Palomo, E.; González Viñas, M.A.; Díaz-Maroto, M.C.; Soriano-Pérez, A.; Pérez-Coello, M.S. Aroma potential of Albillo wines and effect of skin-contact treatment. Food Chem. 2007, 103, 631-640. [CrossRef]

4. Jiménez Moreno, N.; Ancín Azpilicueta, C. Binding of oak volatile compounds by wine lees during simulation of wine ageing. LWT-Food Sci. Technol. 2007, 40, 619-624. [CrossRef]

5. Liberatone, M.T.; Pati, S.; Del Nobile, M.A.; La Notte, E. Aroma quality improvement of Chardonnay White wine by fermentation and ageing in barrique on lees. Food Res. Int. 2010, 43, 996-1002. [CrossRef]

6. Chatonnet, P.; Dubourdieu, D.; Boidron, J.N. Incidence des conditions de fermentation at d'elevage des vinsblanc secs en barriques sur leur composition in substances cèdèes par le bois de chêne. Sci. Aliments 1992, 12, 665-685.

7. Guchu, E.; Díaz-Maroto, M.C.; Pérez-Coello, M.S.; González Viñas, M.A.; Cabezudo, M.D. Volatile composition and sensory characteristics of Chardonnay wines treated with American and Hungarian oak chips. Food Chem. 2006, 99, 350-359. [CrossRef] 
8. Baiano, A.; Varva, G.; De Gianni, A.; Viggiani, I.; Terracone, C.; Del Nobile, M.A. Influence of type of amphora on physico-chemical properties and antioxidant capacity of "Falanghina" white wines. Food Chem. 2014, 146, 226-233. [CrossRef] [PubMed]

9. Lukic, I.; Jedrejcic, N.; KovacevicGanic, K.; Staver, M.; Persuric, D. Phenolic and aroma composition of white wines produced by prolonged maceration and maturation in wooden barrels. Food Tech. Biotech. 2015, 53, 407-418.

10. Alañón, M.E.; Marchante, L.; Alarcón, M.; Díaz-Maroto, I.J.; Pérez-Coello, S.; Díaz-Maroto, M.C. Fingerprints of acacia aging treatments by barrels or chips based on volatile profile, sensorial properties, and multivariate analysis. J. Sci. Food Agric. 2018, 98, 5795-5806. [CrossRef] [PubMed]

11. Delia, L.; Jordão, A.M.; Ricardo Da Silva, J.M. Influence of different wood chips species (oak, acacia and cherry) used in a short period of aging on the quality of Encruzado white wines. Mitt. Klosterneubg. 2017, 67, 84-96.

12. Fernández de Simón, B.; Esteruelas, E.; Muñoz, A.M.; Cadahía, E.; Sanz, M. Volatile compounds in acacia, chestnut, cherry, ash, and oak woods, with a view to their use in cooperage. J. Agric. Food Chem. 2009, 57, 3217-3227. [CrossRef] [PubMed]

13. Alañón, M.E.; Castro-Vázquez, L.; Díaz-Maroto, M.C.; Pérez-Coello, M.S. Aromatic potential of Castanea sativa Mill. Compared to Quercus species to be used in cooperage. Food Chem. 2012, 130, 875-881. [CrossRef]

14. Alarcón, M.; Díaz-Maroto, M.C.; Pérez-Coello, M.S.; Alañón, M.E. Isolation of natural flavoring compounds from cooperage woods by pressurized hot water extraction (PHWE). Holzforschung 2018. [CrossRef]

15. Guchu, E.; Díaz-Maroto, M.C.; Díaz-Maroto, I.J.; Vila-Lameiro, P.; Pérez-Coello, M.S. Influence of the species and geographical location on volatile composition of Spanish oak wood (Quercus petraea Liebl. and Quercus robur L.). J. Agric. Food Chem. 2006, 54, 3062-3066. [CrossRef] [PubMed]

16. Díaz-Maroto, M.C.; Guchu, E.; Castro-Vázquez, L.; de Torres, C.; Pérez-Coello, M.S. Aroma-active compounds of American, French, Hungarian and Russian oak Woods, studied by GC-MS and GC-O. Flavour Fragr. J. 2008, 23, 93-98. [CrossRef]

17. Prida, A.; Puech, J.L. Influence of geographical origin and botanical species on the content of extractives in American, French, and East European oak woods. J. Agric. Food Chem. 2006, 54, 8115-8126. [CrossRef] [PubMed]

18. Díaz-Maroto, I.J.; Vila-Lameiro, P.; Guchu, E.; Díaz-Maroto, M.C. A comparison of the autecology of Quercus robur L. and Q. pyrenaica Wild. present habitat in Galicia, NW Spain. Forestry 2007, 80, 223-239. [CrossRef]

19. Spillman, P.J.; Sefton, M.A.; Gawel, R. The contribution of volatile compounds derived during oak barrel maturation to the aroma of a Chardonnay and Cabernet Sauvignon wine. Aust. J. Grape Wine Res. 2004, 10, 227-235. [CrossRef]

20. Herjavec, S.; Jeromel, A.; Da Silva, A.; Orlic, S.; Redzepovic, S. The quality of white wines fermented in Croatian oak barrels. Food Chem. 2007, 100, 124-128. [CrossRef]

21. Prida, A.; Chatonnet, P. Impact of oak-derived compounds on the olfactory perception of barrel-aged wines. Am. J. Enol. Vitic. 2010, 61, 408-413.

22. Herrero, P.; Sáenz-Navajas, M.P.; Avizcuri, J.M.; Culleré, L.; Balda, P.; Antón, E.C.; Ferreira, V.; Escudero, A. Study of chardonnay and Sauvignon blanc wines form D.O.Ca Rioja (Spain) aged in different French oak wood barrels: Chemical and aroma quality aspects. Food Res. Int. 2016, 89, 227-236. [CrossRef] [PubMed]

23. Rodríguez-Nogales, J.M.; Fernández-Fernández, E.; Vila-Crespo, J. Characterisation and classification of Spanish Verdejo young white wines by volatile and sensory analysis with chemometric tools. J. Sci. Food Agric. 2009, 89, 1927-1935. [CrossRef]

24. Gutiérrez Afonso, V.L. Sensory descriptive analysis between white wines fermented with oak chips and in barrels. J. Food Sci. 2002, 67, 2415-2419. [CrossRef]

25. Aleixandre, J.L.; Padilla, A.I.; Navarro, L.L.; Suria, A.; García, M.; Álvarez, I. Optimisation of making barrel-fermented dry Muscatel wines. J. Agric. Food Chem. 2003, 51, 1889-1893. [CrossRef] [PubMed]

26. Nunes, P.; Muxagata, S.; Correia, A.C.; Nunes, F.M.; Cosme, F.; Jordao, A.M. Effect of oak wood barrel capacity and utilization time on phenolic and sensorial profile evolution of an Encruzado white wine. J. Sci. Food Agric. 2017, 97, 4847-4856. [CrossRef] [PubMed]

27. Ortega-Heras, M.; González-Sanjosé, M.L.; González-Huerta, C. Consideration of the influence of ageing process, type of wine and oenological classic parameters on the levels of wood volatile compounds present in red wines. Food Chem. 2007, 103, 1434-1448. [CrossRef] 
28. Karbowiak, T.; Gougeon, R.D.; Alinc, J.B.; Brachais, L.; Debeaufort, F.; Voilley, A.; Chassagne, D. Wine oxidation and the role of cork. Crit. Rev. Food Sci. Nutr. 2009, 50, 20-52. [CrossRef]

29. Pérez-Coello, M.S.; González-Viñas, M.A.; García-Romero, E.; Cabezudo, M.D.; Sanz, J. Chemical and sensory changes in white wines fermented in the presence of oak chips. Int. J. Food Sci. Technol. 2000, 35, $23-32$. [CrossRef]

30. Sánchez-Palomo, E.; Alonso-Villegas, R.; Delgado, J.A.; González-Viñas, M.S. Improvement of Verdejo white wines by contact with oak chips at different winemaking stages. LWT-Food Sci. Technol. 2017, 79, 111-118. [CrossRef]

31. Zea, L.; Moyano, L.; Moreno, J.A.; Medina, M. Aroma series as fingerprints for biological ageing in fino sherry-type wines. J. Sci. Food Agric. 2007, 87, 2319-2326. [CrossRef]

32. Cadwallader, K.R. Potent odorants in hickory and mesquite smokes and liquid smoke extracts. In Proceedings of the Annual Meeting of the Institute of Food Technologies, New Orleans, LA, USA, 22-26 June 1996; pp. 34-36.

33. Sunao, M.; Ito, T.; Hiroshima, K.; Sato, M.; Uehara, T.; Ohno, T.; Watanabe, S.; Takahashi, H.; Hashizume, K. Analysis of volatile phenolic compounds responsible for 4-vinylguaiacol-like odor characteristics of sake. Food Sci. Technol. Res. 2016, 22, 111-116. [CrossRef]

34. Escudero, A.; Campo, E.; Fariña, L.; Cacho, J.; Ferreira, V. Analytical characterization of the aroma of five Premium red wines. Insights into the role of odor families and the concept of fruitiness of wines. J. Agric. Food Chem. 2007, 55, 4501-4510. [CrossRef] [PubMed]

35. López, R.; Aznar, M.; Cacho, J.; Ferreira, V. Determination of minor and trace volatile compounds in wine by solid-phase extraction and gas chromatography with mass spectrometric detection. J. Chromatogr. A 2002, 966, 167-177. [CrossRef]

36. Etievant, P.X. Wine. In Volatile Compounds in Foods and Beverages; Marse, H., Ed.; Marcek Dekker, Inc.: New York, NY, USA, 1991; pp. 483-587.

37. Cutzach, I.; Chatonnet, P.; Dubourdieu, D. Study of the formation mechanisms of some volatile compounds during aging of sweet fortified wines. J. Agric. Food Chem. 1999, 47, 2837-2846. [CrossRef] [PubMed]

38. Alañón, M.E.; Schumacher, R.; Castro-Vázquez, L.; Díaz-Maroto, M.C.; Pérez-Coello, M.S. Enological potential of chestnut wood for aging Tempranillo wines Part I: Volatile compounds and sensorial properties. Food Res. Int. 2013, 51, 325-334. [CrossRef]

39. Alañón, M.E.; Schumacher, R.; Castro-Vázquez, L.; Díaz-Maroto, M.C.; Hermosín, I.; Pérez-Coello, M.S. Enologial potential of chestnut wood for aging Tempranillo wines Part II: Phenolic compounds and chromatic characteristics. Food Res. Int. 2013, 51, 536-546. [CrossRef]

40. Chinnici, F.; Natali, N.; Bellachioma, A.; Versari, A.; Riponi, C. Changes in phenolic composition of red wines aged in cherry wood. LWT-Food Sci. Technol. 2015, 60, 977-984. [CrossRef]

41. Chinnici, F.; Natali, N.; Sonni, F.; Bellachioma, A.; Riponi, C. Comparative changes in color features and pigment composition of red wines aged in oak and cherry wood casks. J. Agric. Food Chem. 2011, 59, 6575-6582. [CrossRef] [PubMed]

42. De Rosso, M.; Paniguel, A.; Dalla Vedova, A.; Stella, L.; Flamini, R. Changes in chemical composition of a red wine aged in acacia, cherry, chestnut, mulberry and oak wood barrels. J. Agric. Food Chem. 2009, 57, 1915-1920. [CrossRef] [PubMed]

43. Fernández de Simón, B.; Martínez, J.; Sanz, M.; Cadahía, E.; Esteruelas, E.; Muñoz, A.M. Volatile compounds and sensorial characterization of red wine aged in cherry, chestnut, false acacia, ash and oak wood barrels. Food Chem. 2014, 147, 346-356. [CrossRef] [PubMed]

44. Fernández de Simón, B.; Sanz, M.; Cadahía, E.; Martínez, J.; Muñoz, A.M. Polyphenolic compounds as chemical markers of wine ageing in contact with cherry, chestnut, false acacia, ash and oak wood. Food Chem. 2014, 143, 66-76. [CrossRef] [PubMed]

45. Sanz, M.; Fernández de Simón, B.; Esteruelas, E.; Muñóz, A.M.; Cadahía, E.; Hernández, T.; Estrella, I.; Martínez, J. Polyphenols in red wine aged in acacia (Robinia pseudoacacia) and oak (Quercus petraea) wood barrels. Anal. Chim. Acta 2012, 732, 83-90. [CrossRef] [PubMed]

46. Gortzi, O.; Metaxa, X.; Mantanis, G.; Lalas, S. Effect of artificial ageing using different wood chips on the antioxidant activity, resveratrol and catechin concentration, sensory properties and color of two Greek red wines. Food Chem. 2013, 141, 2887-2895. [CrossRef] [PubMed] 
47. Kyraleou, M.; Kallithraka, S.; Chira, K.; Tzanakouli, E.; Ligas, I.; Kotseridis, Y. Differentiation of wines treated with wood chips based on their phenolic content, volatile composition, and sensory parameters. J. Food Sci. 2015, 80, C2701-C2710. [CrossRef] [PubMed]

48. Psarra, C.; Gortzi, O.; Dimitirs, P.M. Kinetics of polyphenol extraction from wood chips in wine models solutions: Effect of chip amount and botanical species. J. Inst. Brew. 2015, 121, 207-212. [CrossRef]

49. Alañón, M.E.; Castro-Vázquez, L.; Díaz-Maroto, M.C.; Hermosín-Gutiérrez, I.; Gordon, M.H.; Pérez-Coello, M.S. Antioxidant capacity and phenolic composition of different woods used in cooperage. Food Chem. 2011, 129, 1584-1590. [CrossRef]

50. Kozlovic, G.; Jeromel, A.; Maslov, L.; Pollnitz, A.; Orlic, S. Use of acacia barrique barrels-Influence on the quality of Malvazija from Istria wines. Food Chem. 2010, 120, 698-702. [CrossRef]

51. Culleré, L.; Fernández de Simón, B.; Cadahía, E.; Ferreira, V.; Hernández Orte, P.; Cacho, J. Characterization by gas chromatography-olfactometry of the most odor-active compounds in extracts prepared from acacia, chestnut, cherry, ash and oak woods. LWT-Food Sci. Technol. 2013, 53, 240-248. [CrossRef]

52. Pérez-Coello, M.S.; Sánchez, M.A.; García, E.; González-Viñas, M.S.; Sanz, J.; Cabezudo, M.D. Fermentation of white wines in the presence of wood chips of American and French oak. J. Agric. Food Chem. 2000, 48, 885-889. [CrossRef] [PubMed]

53. Young, O.A.; Kaushal, M.; Robertson, J.D.; Burns, H.; Nunns, S.J. Use of species other than oak to flavor wine: An exploratory survey. J. Food Sci. 2010, 75, S490-S498. [CrossRef] [PubMed]

(C) 2018 by the authors. Licensee MDPI, Basel, Switzerland. This article is an open access article distributed under the terms and conditions of the Creative Commons Attribution (CC BY) license (http://creativecommons.org/licenses/by/4.0/). 